\title{
PENINGKATAN KETERAMPILAN MEMBACA DAN BERPIKIR KRITIS SISWA SMA MELALUI METODE STRATTA
}

\author{
Lia Nur Safitri ${ }^{1}$, Ardila Putri Cantika ${ }^{2}$, Evi Chamalah ${ }^{3}$ \\ Universitas Islam Sultan Agung \\ Email: lianursafitri@std.unissula.ac.id ${ }^{1}$
}

\begin{abstract}
Abstrak: Penelitian ini bertujuan untuk meningkatkan keterampilan membaca dan berpikir kritis siswa SMA melalui metode stratta. Metode stratta berasal dari penulisan Leslei Stratta dalam . Metode penelitian yang digunakan dalam penelitian ini adalah penelitian dan pengembangan (research and development/ $R \& D$ ). Pengumpulan data pada penelitian ini dilakukan dengan meneliti keadaan belajar mengajar siswa SMA saat ini. Penelitian ini menghasilkan beberapa skenario untuk meningkatkan ketrampilan membaca dan berpikir kritis siswa SMA melalui metode stratta. Peningkatan ketrampilan membaca dan berpikir kritis pada siswa dapat di kembangkan dan menghasilkan sebuah karya baik sastra ataupun non sastra. Pada setiap pembelajaran terdapat beberapa skenario yang bisa diterapkan saat proses belajar mengajar. Tahap penjelajahan pada pembelajaran sastra terdapat 5 skenario dan pada pembelajaran non sastra terdapat 6 skenario. Pada tahap interpretasi dan tahap rekreasi terdapat 4 skenario pada pembelajaran sastra dan non sastra.
\end{abstract}

Kata Kunci. Metode stratta, berpikir kritis, keterampilan membaca.

\section{IMPROVING THE SKILLS OF READING AND THINKING THE CRITICAL OF HIGH SCHOOL STUDENTS THROUGH THE STRATTA METHOD}

\begin{abstract}
This study aims to improve the reading and critical thinking skills of high school students through the Stratta method. Stratta method is derived from the writing of Leslei Stratta in his book Pattems of Language so it is called the Stratta method. In this method of teaching literature there are three stages that must be done, namely the exploration phase, the interpretation phase and the recreation stage. The research method used in this research is research and development (research and development / $R \& D$ ). Data collection in this study was conducted by examining the current state of teaching and learning of high school students today. This study produced several scenarios to improve the reading and critical thinking skills of high school students through the Stratta method. Improved reading skills and critical thinking in students can be developed and produce a work both literary or non-literary. In each learning there are several scenarios that can be applied during the teaching and learning process. The exploration stage in the study of literature there are 5 scenarios and in non-literary learning there are 6 scenarios. At the interpretation and recreation stages there are 4 scenarios in literary and non-literary learning.
\end{abstract}

Keywords: Stratta method, critical thinking, reading skill.

\section{PENDAHULUAN}

Membaca merupakan kegiatan yang menjadi salah satu aspek dalam keterampilan berbahasa yang memiliki peranan penting dalam pengetahuan seseorang pada pembelajaran maupun kehidupan sehari-hari. Penelitian yang telah dilaksanakan oleh PISA (2015)

BASASTRA Jurnal Bahasa, Sastra,dan Pengajarannya

Volume 8 Nomor 2, Oktober 2020, P-ISSN 2302-6405, E-ISSN 2714-9765 
bahwa pemahaman tingkat membaca peserta didik di Indonsia masih tergolong rendah. PISA menunjukkan bahwa Indonesia menempati peringkat 64 dari 72 negara. Dillihat dari rendahnya keterampilan membaca akan berpengaruh pada keterampilan berpikir kritis. Untuk mengatasi permasalahan ini, Peraturan Menteri Pendidikan dan Kebudayaan Nomor 23 tahun 2015 mengadakan Gerakan literasi, yaitu kegiatan 15 menit untuk membaca buku nonpelajaran sebelum kegiatan belajar mengajar dimulai.

Budaya literasi memberikan banyak manfaat dalam kehidupan masyarakat, jika dihubungkan dengan budi pekerti manfaat membaca dapat meningkatkan hubungan sosial, dapat meningkatkan empati seseorang dan membantu kita menghubungkan dengan dunia luar. Keterampilan membaca tidak tumbuh begitu saja, akan tetapi bisa ditanamkan sejak dini mulai dari lingkungan keluarga, masyarakat, sekolah dan dunia pekerjaan. Di dalam sekolah sudah banyak yang menerapkan gerakan literasi, banyak yang menggunakan karya sastra sebagai objek bacaan.

Karya sastra diciptakan oleh sastrawan adalah untuk dinikmati, dipahami, dan dimanfaatkan oleh masyarakat (Damono, 1984:1). Salah satu jenis karya sastra yang menjadi bahan bacaan yang digemari oleh remaja dikalangan SMA adalah novel. Karena isinya yang mengandung hiburan, imajinasi dan muatan moral serta bahasanya yang mudah dipahami membuat mereka tidak merasa jenuh untuk membacanya. Dengan membaca novel bisa menjadi alternatif untuk melatih keterampilan membaca dan berpikir kritis siswa. karena pada dasarnya jenjang sekolah menengah atas sudah menuntut siswanya untuk berlatih berpikir kritis.

Keterampilan membaca dan berpikir kritis dapat dilatih dengan menggunakan karya sastra sebagai objek pembelajarannya. Tidak hanya dalam pembelajaran karya sastra saja akan tetapi dapat dikaitkan dengan pembelajaran bahasa indonesia yang lainnya. Dalam kegiatan pembelajaran pengajar memiliki peranan penting. Pengajar adalah perancang, penggerak, dan fasilitator yang berperan menafsirkan situasi sehingga sanggup melakukan modifikasi strategi dan tekhnik pengelolaan pembelajaran secara tepat (Djojosubroto, 2005: 63). Di dalam pembelajaran dibutuhkan metode yang tepat untuk mencapi tujuan yang diharapkan. Salah satu metode yang bisa digunakan dalam pembelajaran sastra ( novel, puisi, cerpen dll) yaitu metode stratta. Langkah-langkah yang dilakukan dalam metode stratta dapat melatih siswa untuk memiliki keterampilan membaca dan berpikir kritis..

Dalam penelitian ini metode stratta tidak hanya terfokus dalam pembelajaran sastra akan tetapi, bisa dikaitkan dengan pembelajaran materi bahasa Indonesia SMA. Rumusan 
masalah dari peneilitian ini adalah bagaimana meningkatkan keterampilan membaca dan berpikir kritis siswa SMA melalui metode stratta. Adapun tujuan dari penelitian ini adalah mengetahui tentang metode stratta. Serta mengetahui cara meningkatkan keterampilan membaca dan berpikir kritis siswa SMA melalui metode stratta.

Suatu penelitian akan lebih kuat jika mendapat dukungan dari hasil penelitian sebelumnya, dari penelitian Anwar Balfas (2008) yang berjudul Pengembangan Kemampuan Literasi dan Berpikir Kritis Siswa Melalui Pembelajaran Sastra Berbasis Konteks yang menggunakan kontekstual yang berisi berbagai kiat pembelajaran sastra yang terdiri dari 5 kiat pembelajaran meliputi relating, experiencing, applying, cooperative, dan transferring. Penerapan dari 5 kiat pembelajaran tersebut jika dipraktikkan dalam kegiatan belajar mengajar terfokus dalam pembelajaran sastra.

Sedangkan dalam penelitian Muh Amin (2016) yang berjudul Analisis Penggunaan Strategi Stratta dalam Pembelajaran Menulis Puisi Siswa Kelas XI SMA Negeri 1 Sungguminasa dan penelitian dari R. Mudya Fabionus (2019) yang berjudul Ketrampilan Mengonversi Teks Cerpen Tragedi Di Meja Makan Menjadi Teks Drama Tragedi dengan Strategi Stratta Siswa Kelas IX MIA4 SMA Negeri Makassar. Dari kedua penelitian tersebut merupakan penerapan dari metode stratta dalam pembelajaran sastra, berdasarkan hasil penelitian pembelajaran stratta efektif untuk diterapkan dalam pembelajaran sastra. Pada dasarnya metode stratta digunakan dalam pembelajaran sastra akan tetapi jika mampu untuk diterapkan dalam materi pembelajaran lainnya maka bisa dicoba untuk diterapkan.

\section{METODE}

Metode penelitian yang digunakan dalam penelitian ini adalah penelitian dan pengembangan (research and development/ $R \& D$ ). Dalam bidang pendidikan, Bord and Gall (1998) menyatakan bahwa penelitian dan pengembangan (research and development/R\&D) merupakan metode penilitian yang digunakan untuk mengembangkan atau memvalidasi produk-produk yang digunakan dalam pendidikan dan pembelajaran (Sugiono, 2016:4). Penelitian dan pengembangan dalam konteks pendidikan (educational research and development) merupakan proses yang digunakan untuk mengembangkan dan memvalidasi produk-produk pendidikan, seperti buku ajar, strategi/model/metode/program pembelajaran atau pelatihan.

Metode R\&D menurut Sukmadinata (2006) dibagi menjadi tiga tahap penelitian pengembangan yaitu studi pendahuluan, uji coba pengembangan model dan uji produk akhir serta sosialisasi hasil. Karena 
penelitian yang dilakukan merupakan penelitian tentang pengembangan motode pembelajaran yang bertujuan untuk meningkatkan kualitas dan hasil belajar, maka peneliti menggunakan pendekatan R\&D.

\section{HASIL DAN PEMBAHASAN}

Metode Stratta, metode stratta berasal dari penulisan Leslei Stratta dalam bukunya Pattems of Language sehingga dinamakan metode stratta. Dalam metode ini mengajarkan sastra ada tiga tahap yang harus dilakukan yaitu tahap penjelajahan, tahap interpretasi dan tahap rekreasi. Ketiga tahap dalam metode stratta masingmasing memiliki tahapan tersendiri dan apabila satu tahapan memiliki peranan penting demi keberhasilan tahapan berikutnya. Dari tiga tahap, tahap yang pertama dan menjadi dasar dari tahapan berikutnya yaitu tahap penjelajahan. Kemudian yang menjadi titik tengah yaitu tahap interpretasi. Dan yang menjadi puncak akhir atau tahap penyelesaian yaitu tahap re-kreasi. Tahap penjelajahan adalah tahap memahami atau menghayati karya sastra. Penjelajahan dapat dilakukan dengan membaca, bertanya, mengamati, dan kegiatan lain yang bertujuan untuk mendapatkan pemahaman tentang karya sastra yang sedang dijelajahi. Tahap interpretasi adalah tahap penafsiran terhadap karya sastra yang telah dijelajahi. Penafsiran dapat dilakukan pada unsur-unsur yang membentuk sebuah karya sastra. Dapat pula dikaitkan dengan peristiwaperistiwa yang pernah dialami. Tahap re-kreasi adalah tahap pendalaman. Mengkreasikan kembali atau penciptaan kembali karya sastra baru sesuai dengan pemahaman dan penafsiran dari karya sastra yang telah dibaca sebelumnya.

Pada dasarnya metode stratta digunakan untuk pembelajaran sastra akan tetapi dalam penelitian ini metode stratta dikembangkan menjadi metode untuk pembelajaran materi pelajaran bahasa Indonesia yang lainnya. Dalam pembelajaran bahasa Indonesia tidak semua materi bisa diterapkan dengan menggunakan metode stratta, perlu dilakukan kajian mana yang bisa diterapkan dan mana yang tidak bisa untuk diterapkan. Materi yang bisa diterpakan yakni materi yang membutuhkan dan mencakup tiga tahap dalam metode stratta atau disebut dengan kegiatan pembelajaran membangun konteks. Yang termasuk dalam kegiatan utama pembelajaran berbasis teks, yaitu membangun konteks dan percontohan teks ideal. Tujuan akhir dari pembelajaran berbasis teks adalah menjadikan pembelajaran memahami serta mampu menggunakan teks sesuai dengan tujuan sosial dari teks-teks yang dipelajari (Mahsun, 2014: 112). Dalam pembelajaran berbasis teks dapat mendorong siswa untuk berpikir kritis, mengeksplore pengalaman yang telah dimiliki untuk diterapkan dalam pembelajaran 
Model pembelajaran stratta ditemukan oleh ahli pendidikan bernama Leslei Stratta. Model ini meliputi tiga langkah pokok yaitu penjelajarhan, interpretasi, dan rekreasi pendalaman. Hal tersebut berarti diawali dari siswa mengenali bacaan, kemudian menginterpretasi unsurunsurnya, dan terakhir mengolah kembali menjadi karya baru (Endraswara 2005:95-96). Model stratta telah lama didengungkan oleh pakar-pakar pendidikan di Indonesia, khususnya dalam pembelajaran menyimak ( S Haryadi, 2013) Model ini merupakan model yang cocok untuk aspek menulis. Model stratta adalah model yang mengikuti pola pengajaran yang berproses. Model ini diharapkan dapat mendorong siswa untuk aktif, kreatif, dan inovatif selama proses pembelajaran. Contoh model stratta sejalan dengan pendekatan pembelajaran konstektual yang dirancang agar siswa mampu membangun pemahaman sendiri secara aktif, kreatif, dan produktif, stimulasi harus dapat membangun kembali pengalaman atau pengetahuan yang telah dimiliki siswa ( Riana 2019: 552553).

Salah satu hal yang dibutuhkan ketika pembelajaran sastra dinilai belum mendapat hasil yang maksimal adalah peningkatan pembelajaran sastra. Disadari atau tidak pembelajaran sastra dapat melalui penelitian pembelajaran sastra (Arif Hidayat 2009: 2-5).
Berdasarkan pendapat diatas, dapat disimpulkan bahwasanya metode stratta dapat digunakan dalam pembelajaran bahasa Indonesia, karena metode stratta merupakan metode yang dapat mencakup pembelajaran yang ada dalam materi bahasa Indonesia.

Lalu peneliti melakukan analisis materi pelajaran bahasa indonesia yang sekiranya bisa dipraktikkan dalam pembelajaran dengan menggunakan metode stratta. Adapun metode stratta bisa digunakan untuk pembelajaran dengan materi dapat dilihat pada table berikut ini:

Tabel 1. Pembelajaran sastra dan nonsastra SMA

\begin{tabular}{cccc}
\hline $\begin{array}{c}\text { Bentuk } \\
\text { pembelajar } \\
\text { an }\end{array}$ & $\begin{array}{c}\text { Kelas } \\
\text { X }\end{array}$ & $\begin{array}{c}\text { Kelas } \\
\text { XI }\end{array}$ & $\begin{array}{c}\text { Kelas } \\
\text { XII }\end{array}$ \\
\hline Sastra & Puisi & Cerpen & Novel \\
& Hikayat & Drama & Drama \\
& & Novel & \\
\hline & & Teks & Teks \\
& Lapora & Prosedur & Editori \\
& n hasil & Teks & al \\
& observa & Eksplan & Kritik \\
& si & asi & \\
& Teks & Teks & \\
& Eksposi & Eksposis & \\
& si & i & \\
& Anekdo & Ceramah & \\
& t Teks & & \\
& Negosia & &
\end{tabular}

Melalui metode stratta dapat ditawarkan kiat pembelajaran sastra dan non sastra sebagai berikut:

Tahap Penjelajahan

Pada tahap penjelajahan ini dapat dilakukan dengan kegiatan yang bertujuan untuk mendapatkan 
pemahaman tentang karya sastra ataupun non sastra yang meliputi kegiatan membaca, bertanya, mengamati dan memahami.

\section{Pembelajaran Sastra}

Bentuk pembelajaran sastra menekankan pada belajar sastra dalam lingkup kehidupan dan budaya Indonesia. Guru hendaknya mencari referensi bahan yang sesuai dengan kehidupan nyata dan budaya Indonesia, yaitu bisa mengambil karya sastra yang lahir dari sastrawan-sastrawan Indonesia. Pembelajaran semacam ini dalam masa depan yang panjang bertujuan memberikan kontribusi pada kebudayaan Indonesia yang luhur. Terdapat beberapa pengarang yang menghasilkan karya lokalitas dengan baik diantaranya Ahamd Tohari dalam novelnya Ronggeng Dukuh Paruk, Mochtar Lubis yang mengangkat lokalitas kerinci dalam novelnya Harimau-harimau. Novel Bumi Manusia oleh Pramoedya Ananta Tour dengan nuansa kebudayaan jawa, demikian juga dalam prosa lirik Pengakuan Pariyem karya Linus Suryadi A.G, dan sajak-sajak W.S Rendra yang bernuansa religius. Karya sastra yang menggambarkan kondisi Indonesia pada masa orde baru diantaranya yaitu drama Lautan Jilbab karya Enha Ainun Najib. Kemudian pada masa orde reformasi terdapat kumpulan puisi yang menggambarkan budaya dan kondisi budaya Indonesia dengan judul Ayat-Ayat Api karya Supardji Joko Damono.

Skenario pertama untuk pembelajaran sastra:

(1) Siswa diharapkan untuk membaca dan memahami karya sastra seorang sastrawan.

(2) Siswa diminta untuk menggali dan menemukan pertanyaan terkai dengan karya sastra yang telah dibaca.

(3) Siswa diminta untuk mengajukan pertanyaan yang telah ditemukan dan dipahami.

(4) Siswa diminta untuk menelaah biografi sastrawan yang bersangkutan.

(5) Siswa diminta untuk menguraikan hasil telaah biografi sastrawan untuk memahami lebih mendalam karya sastra yang ditelaah.

Mengenai skenario pertama dapat dijelaskan bahwa siswa dapat membaca dan memahami berbagai karya sastra seorang sastrawan dengan mendalami makna dari karya sastra seorang sastrawan, selanjutnya siswa dapat menemukan beberapa pertanyaan yang ada dalam karya sastra yang sudah dibaca dan dipahami sebelumnya, setelah itu siswa dapat menelaah biografi dari sastrawan dengan membaca latar belakang sastrawan dan menguraikannya.

\section{Pembelajaran Non Sastra}

Bentuk pembelajaran non sastra mengacu pada materi yang hendak diajarkan. Guru menyediakan garis 
besar atau poin-poin pokok materi yang akan dipelajari. Pada tahap ini siswa bisa mencari bahan referensi bacaan dari buku ataupun internet dan dalam pemantauan guru. Dalam pembelajaran SMA terdapat beberapa materi yang bisa diterapkan menggunakan metode stratta. Pada pembelajaran kelas $\mathrm{X}$ misalnya pada materi Laporan Hasil Observasi, Teks Eksposisi, Anekdot, Teks Negosiasi. Adapun pada pembelajaran kelas XI yaitu pada materi Teks Prosedur, Teks Eksplanasi, Ceramah,. Kemudian pada pembelajaran kelas XII terdapat materi Teks Editorial, dan Kritik.

Skenario pertama untuk pembelajaran non sastra:

(1) Guru memberikan bekal garis besar materi.

(2) Siswa diharapkan untuk membaca dan memahami materi yang akan diajarkan.

(3) Siswa diminta untuk menggali dan menemukan pertanyaan terkai dengan teks yang dibaca.

(4) Siswa diminta untuk mengajukan pertanyaan yang telah ditemukan dan dipahami.

(5) Siswa diminta untuk menelaah contoh teks yang telah disediakan oleh guru atau siswa mencari teks itu sendiri.

(6) Siswa diminta untuk menguraikan hasil telaah terhadap contoh teks yang telah dipahami.

Dari skenario pertama dalam pemebalajaran non sastra, siswa lebih ditekankan dalam sebuah materi yang dimana siswa nantinya diminta untuk menentukan pertanyaan terkait dengan materi yang diberikan oleh guru. Setelah memberikan pertanyaan, siswa diminta untuk menelaah isi teks yang ada dalam materi tersebut sehingga nantinya siswa dapat memberikan hasil berupa contoh teks yang sesuai dengan materi.

\section{Tahap Interpretasi}

Tahap interpretasi adalah tahap penafsiran terhadap karya sastra yang telah dijelajahi. Penafsiran dapat dilakukan pada unsur-unsur yang membentuk sebuah karya sastra. Tahap interpretasi dapat diartikan sebagai pengimajinasian anak terhadap sesuatu yang pernah dialami. Hal ini membantu konsep belajar seorang guru dalam perkembangan materi belajar dengan imajinasi anak sesuai kemampuan. Melalui tahap ini, hasil pembelajaran lebih bermakna bagi siswa. Pada tahap ini, proses belajar bersifat alami karena siswa dapat bekerja dengan menggunakan imajinasi siswa. Siswa dapat berfikir kritis untuk mengembangkan imajinasinya ke dalam kegiatan belajar mengajar yang sedang berlangsung. Pada tahap ini, guru biasanya memanfaatkan imajinasi siswa untuk mengarang dan mengaitkan terhadap pembelajaran yang sedang diajarkan. Dengan mengarang dan mengaitkan membuat memori sang anak dapat berkembang dan menjadikannya selalu teringat terhadap pembelajaran yang sedang diterima karena pada pembelajaran 
tersebut berkaitan dengan hal-hal yang pernah dialami oleh siswa.

\section{Pembelajaran Sastra}

Tujuan kegiatan pembelajaran sastra ini adalah belajar menerapkan pengalaman hasil belajar ke dalam penggunaan dan kebutuhan praktis.

Skenario kedua pembelajaran sastra:

(1) Siswa diharapkan untuk berkonsentrasi dalam berimajinasi.

(2) Siswa diminta untuk menggali memori untuk mengaitkan konsep pembelajaran dengan hal-hal yang pernahdialami.

(3) Siswa diharapkan dapat bercerita sesuai kemampuan dalam bentuk karya sastra.

(4) Guru berharap siswa dapat lebih tangkas dalam berfikir dan berani menuangkan gagasannya.

Skenario itu dapat dilakukan siswa untuk melatih diri siswa agar menjadi siswa terdidik dan membanggakan. Dengan memanfaatkan imajinasi siswa, siswa nantinya dapat mengahasilkan senuah produk berupa karya. Pada tahap ini siswa dapat menyambungkan memorinya dalam kegiatan belajar mengajar. Guru membantu siswa dalam mengingat suatu hal yang pernah di alami dengan menambah imajinasi siswa dalam kegiatan belajar mengajar. Misalnya terdapat siswa yang sedang menjalin hubungan jarak jauh bisa mengirimkan bentuk puisi Cintaku Jauh Di Pulau karya Chairil Anwar berikut ini:
Cintaku jauh di pulau, Gadis manis, sekarang iseng sendiri Perahu melancar, bulan memancar, di leher kukalungkan oleh-oleh buat si pacar. Angin membantu, laut terang, tapi terasa aku tidak kan sampai padanya. Di air yang tenang, di angin mendayu, di perasaan penghabisan segala melaju ajal bertakhta, sambil berkata "tujukan perahu ke pangkuanku saja," Amboi jalan sudah bertahun ku tempuh! Perahu yang bersama kan merapuh! Mengapa ajal memanggil dulu sebelum sempat berpeluk dengan cintaku? Manis jauh di pulau, kalau ku mati, dia mati iseng sendiri.

\section{Pembelajaran Non Sastra}

Pada tahap ini jika diterapkan dalam pembelajaran non sastra siswa dilatih untuk mengaitkan materi sesuai yang diajarkan dengan pengalaman yang telah dialami oleh siswa. Skenario kedua pembelajaran non sastra:

(1) Setelah mengamati teks, siswa mampu menggali pikiran sesuai dengan pengalaman yang telah dilalui.

(2) Guru bisa melatih ketangkasan pikiran siswa dengan cara bertanya terkait dengan teks dan kejadian apa yang pernah dialami oleh siswa. 
(3) Guru dapat membantu mengaitkan hal-hal yang pernah dialami oleh siswa terhadap pembelajaran pada saat itu.

(4) Siswa dapat menghubungkan pikiran yang telah dirancang terhadap hal-hal yang pernah dialami dengan materi yang sedang berlangsung.

Skenario tersebut bertujuan untuk pembelajaran melekat seaca mendalam dalam pemikiran siswa. karena pada tahap ini siswa mempu berpikir kritis untuk mengaitkan konsep pembelajaran dengan peristiwa yang pernah dialami. Misalnya: Siswa pernah mengalami kejadian lucu maka siswa mampu mengaitkan materi Cerita Anekdot dengan peristiwa tersebut.

Siswa dapat memasak dengan prosedur yang baik, dari peristiwa itu siswa mampu mengaitkan pengalamannya ke dalam materi Teks Prosedur. Siswa pernah mendatangi kajian islam dan dalam kajian tersebut terdapat seseorang yang sedang ceramah, dari peristiwa tersebut siswa dapat mengaitkan dengan materi ceramah. Dalam kehidupan sehari-hari siswa tentunya pernah mendapat kritikan dari seorang teman, guru, orang tua dan lain sebagainya, dari kritikan tersebut siswa dapat mengaitkan dengan materi kritik.

\section{Tahap rekreasi}

Tahap re-kreasi adalah tahap pendalaman. Mengkreasikan kembali atau penciptaan kembali karya sastra maupun non sastra baru sesuai dengan pemahaman dan penafsiran dari karya sastra atau teks yang telah dibaca sebelumnya. Tahap ini merupakan tahap dimana nantinya siswa menghasilkan sebuah produk berupa karya sastra maupun non sastra. Dalam tahap ini siswa dituntut untuk dapat berkarya sesuai kemampuannya dan berdasarkan pengalaman yang telah disusun pada tahap kedua. Dengan bantuan dan pendampingan guru, siswa dilatih untuk menhasilkan karya ataupun teks yang baik dan benar.

\section{Pembelajaran Sastra}

Pada tahap ini bertujuan untuk menghasilkan produk berupa karya sastra dari kretivitas siswa berdasarkan dengan teori dan contoh karya sastra yang telah dibaca pada tahap pertama dan tahap kedua.

Skenario ketiga pembelajaran sastra:

(1) Setelah melalui tahap pertama dan kedua pada pembelajaran sastra siswa dituntut mampu untuk menghasilkan karya sastra sesuai dengan kemampuannya.

(2) Guru membantu siswa untuk menyusun sebuah karya sastra dengan baik dan benar.

(3) Siswa mulai berimajinasi dengan bekal materi dan pengalaman yang telah dimilikinya.

(4) Siswa mulai menyusun karyanya dengan kemampuan yang dimiliki.

Karya sastra yang dimaksud berupa, menghasilkan sebuah puisi ciptaannya masing-masing, cerpen, novel, dan masih banyak lagi sesuai 
dengan tujuan pembelajaran pada waktu itu. Biasanya siswa yang menyukai membaca dan menulis lebih cenderung semangat dalam membuat karya sastra, karena dengan hasil bacaan dan pengalaman yang telah disusun pada tahap interpretasi, yang sudah mereka dapatkan sebelumnya membuat siswa dapat berkarya menggunakan kosa kata yang telah ia rangkai berdasarkan pengalamannya. Dari pengalaman tersebut akan lahir karya sastra dengan berbagai macam sudut pandang kreativitas siswa.

\section{Pembelajaran Non Sastra}

Karya non sastra ini biasanya berupa menceritakan pengalaman lama kembali dengan mengingat memori pada siswa.. Siswa dapat menulis kejadian yang pernah dia alami sebelumnya. Hal ini membuat siswa tangkas dalam mengingat kembali kekadian yang sudah berlangsung serta mampu mengimplementasikan dan mengembangkan peristiwa dalam hidupnya menjadi sebuah teks. Pada tahap ini siswa dituntut untuk menghasilkan produk sebuah teks yang sesuai dengan pembelajaran yang ingin dicapai. Misalnya: Siswa pernah mengalami kejadian lucu maka siswa mampu menyusun peristiwa tersebut menjadi Cerita Anekdot dengan bahasa dan imajinasinya sendiri. Siswa dapat memasak dengan prosedur yang baik, dari peristiwa itu siswa mampu menyusun teks pengalamannya ke dalam bentuk Teks Prosedur. Siswa pernah mendatangi kajian islam dan dalam kajian tersebut terdapat seseorang yang sedang ceramah, dari peristiwa tersebut siswa dapat menyusun teks kedalam bentuk teks ceramah. Dalam kehidupan sehari-hari siswa tentunya pernah mendapat kritikan dari seorang teman, guru, orang tua dan lain sebagainya, dari kritikan tersebut siswa dapat meyusun teks ke dalam bentuk teks kritik.

Skenario ketiga pembelajaran non sastra:

(1) Setelah melalui tahap pertama dan kedua pada pembelajaran non sastra.

(2) Siswa dituntut mampu untuk menghasilkan teks sesuai pengalaman ataupun imajinasinya.

(3) Guru membantu siswa untuk menyusun sebuah teks dengan baik dan benar.

(4) Siswa mulai berimajinasi dengan bekal materi dan pengalaman yang telah dimilikinya.

(5) Siswa mulai menyusun karyanya dengan kemampuan dan mengacu pada unsur-unsur pembanguan teks pada materi yang sedang diajarkan.

Skenario ketiga dalam pembelajaran non sastra, dapat dijelaskan bahwa setelah siswa mampu melalui tahap pertama dan kedua. Siswa dituntut untuk lebih maju lagi dalam artian dapat melewati tahap selanjutnya yaitu tahap ketiga, dimana siswa diminta untuk mengekspresikan atau menuangkan pikiran pribadi untuk 
membentuk suata karya dan tidak lepas dari pendampingan guru.

\section{SIMPULAN}

Berdasarkan penjelasan yang sudah dijelaskan, peningkata keterampilan membaca dan berpikir kritis pada siswa SMA dapat melalui metode stratta. Dalam metode stratta memeiliki 3 tahap yaitu tahap penjelajahan, tahap interpretasi, dan tahap rekreasi. Di masing-masing tahap terdapat 2 pembelajaran yakni pembelajaran sastra dan pembelajaran non sastra. Pada setiap pembelajaran terdapat beberapa skenario yang bisa diterapkan saat proses belajar mengajar. Tahap penjelajahan pada pembelajaran sastra terdapat 5 skenario dan pada pembelajaran non sastra terdapat 6 skenario. Pada tahap interpretasi dan tahap rekreasi terdapat 4 skenario pada pembelajaran sastra dan non sastra.

\section{REFERENSI}

Aanggraini, P. dan Kusniarti, T. (2019). Pembelajaran Sastra Berkearifan Lokal. Malang: UMMPress.

Amin, M. (2016). Analisis Penggunaan Strategi Stratta Dalam Pembelajaran Menulis Puisi Siswa Kelas XI SMA Negeri Sungguminangsa. Konfiks Jurnal Bahasa Sastra dan Pengajarannya, 3 (1), 52-62.

Balvas, A.(2008). Mengembangkan Kemampuan Literasi Dan Berfikir
Kritis Siswa melalui Pembelajaran Sastra Berbasis Konteks, Lingistika journal, 15 (29), 156-159.

Damono, S.D. (1984). Sosiologi Sastra Sebuah Pengantar Ringkas. Jakarta: Pembinaan dan Pengembangan Bahasa.

Djojosubroto, K. (2005). Puisi: Pendekatan dan Pembelajaran. Padang: Dian Dinamika Press.

Endraswara, S. (2005). Metode dan Teori Penagajaran Sastra. Yogyakarta: Buana Pustaka.

Haryadi, S. (2013). Peningkatan Kemampuan Menyimak Berita Dengan Model Audio Dan Model Pembelajaran Stratta Pada Siswa Kelas VII SMP N 13 Purworejo. Jurnal Universitas Muhammadiyah Purworejo, 1 (3) 2425.

Hidayat, A. (2009). Pembelajaran Sastra di Sekolah. Jurnal Pemikiran Alternatif Kependidikan, 14(2), 2-5.

Riana. (2019). Pembelajaran Sastra Di Sekolah. Jurnal Ilmiah Kultura, 20(2). 552-553.

Selamet, R.S. (2018). Dahsyatnya Angin. Jakarta: Bhuana Ilmu Populer.

Sudaryanto. (1993). Metode dan Aneka Tekhnik Analisis Bahasa. Yogyakarta. Duta Wacana University Press.

Sufanti, M. (2015). Penyisipan Pembelajaran Teks Sastra Dalam Pembelajaran Teks Non Sastra Dalam Buku Siswa Bahasa Indonesia SMA. Surakarta: Seminar Nasional Sastra Pendidikan dan Industri Kreatif. 
Sugiyono. (2013). Metode Penelitian Kuantitatif, Kualitatif, dan $R \& D$. Bandung: Alfabeta.

Sukmadinata, N.S. (2009). Metode Penelitian Pendidikan. Bandung: Remaja Rosdakarya. 